\title{
Two new cyclic tetrapeptides from deep-sea bacterium Bacillus amyloliquefaciens GAS 00152
}

\author{
Cheng-Hai Gao ${ }^{1}$, Yin-Ning Chen ${ }^{2}$, Li-Xia Pan ${ }^{1}$, Fu Lei ${ }^{1}$, Bin Long ${ }^{1}$, Li-Qin Hu${ }^{1}$, Rong-Can Zhang ${ }^{1}$, Ke Ke ${ }^{1}$ \\ and Ri-Ming Huang ${ }^{2,3}$
}

The Journal of Antibiotics (2014) 67, 541-543; doi:10.1038/ja.2014.27; published online 2 April 2014

Keywords: Bacillus amyloliquefaciens; cyclic tetrapeptide; cytotoxicity

Marine microorganisms continue to be a productive focus for much of marine natural products investigation. ${ }^{1-3}$ These organisms flourishing in diverse marine environments, have produced a wide variety of structurally unique and biologically active secondary metabolites many of which have attracted considerable attention., ${ }^{1,4}$ In the last decades, the number of reported secondary metabolites from marine bacteria has steadily increased. ${ }^{2}$ Medium ring-sized peptides containing the amino acids leucine, isoleucine, phenylalanine, valine and proline have been reported from diverse marine sources, including microorganisms. ${ }^{5,6}$ The genus Bacillus has produced biologically active compounds. ${ }^{7,8}$ In our search for bioactive natural products from the bacterium B. amyloliquefaciens collected from South China Sea deep-sea sediment, the culture broth contained two new cyclic tetrapeptides, cyclo-(Leu-Pro-Ile-Pro) (1) and cyclo(Tyr-Pro-Phe-Gly) (2) (Figure 1).

The bacterial strain GAS 00152 was isolated from underwater sediment (depth $2476 \mathrm{~m})$ collected at South China Sea $\left(112^{\circ} 21^{\prime} \mathrm{E}\right.$, $18^{\circ} 24^{\prime} \mathrm{N}$ ), in March, 2011. For taxonomic identification, blast search results at EzTaxon.org Server showed 16S ribosomal RNA gene sequence of the strain GAS 00152 has the highest similarity (100\%) with Bacillus amyloliquefaciens strain CA812 ${ }^{\mathrm{T}}$. A reference specimen was deposited in the Guangxi Key Laboratory of Marine Environmental Science, Guangxi Academy of Sciences, China.

B. amyloliquefaciens GAS 00152 was incubated on a rotary shaker ( 150 r.p.m.) at $28^{\circ} \mathrm{C}$ for 7 days, maintained in $500 \mathrm{ml} \times 600$ conical flasks containing the liquid medium ( $150 \mathrm{ml}$ per flask) composed of peptone $\left(10 \mathrm{gl}^{-1}\right)$ and yeast extract $\left(5 \mathrm{gl}^{-1}\right)$, and seawater after adjusting its $\mathrm{pH}$ to 7.4. The culture broth (90l) of B. amyloliquefaciens GAS 00152 was extracted with EtOAc. The EtOAc extract was concentrated in vacuo to afford $15.37 \mathrm{~g}$ of residue, which was subjected to column chromatography on silica gel, using $\mathrm{CHCl}_{3}-\mathrm{Me}_{2} \mathrm{CO}(10: 0,50: 1,25: 1,10: 1$, and 3:1, v-v) as eluent, giving seven fractions $(A-G)$. Fraction $C$ subjected to a second column chromatography, using $\mathrm{CHCl}_{3}-\mathrm{MeOH}(1: 1, \mathrm{v}-\mathrm{v})$ as eluent, was then separated by HPLC, using a mixture of $\mathrm{MeOH}-\mathrm{H}_{2} \mathrm{O}(55: 45, \mathrm{v}-\mathrm{v})$ to yield $1(5.7 \mathrm{mg})$. Fraction E subjected to a second column chromatography using $\mathrm{CHCl}_{3}-\mathrm{MeOH}(1: 1, \mathrm{v}-\mathrm{v})$ as eluent, was then separated by HPLC, using a mixture of $\mathrm{MeOH}-\mathrm{H}_{2} \mathrm{O}(25: 75, \mathrm{v}-\mathrm{v})$ to yield 2 (7.9 mg).

Compound 1 was obtained as a colorless oil and showed a molecular ion peak at $m / z$ 421.2813 $[\mathrm{M}+\mathrm{H}]^{+}$(calcd for $\mathrm{C}_{22} \mathrm{H}_{37} \mathrm{~N}_{4} \mathrm{O}_{4}$, 421.2815) by HR-ESI-MS consistent with the molecular formula $\mathrm{C}_{22} \mathrm{H}_{36} \mathrm{~N}_{4} \mathrm{O}_{4}$. The ${ }^{1} \mathrm{H}$ NMR (Table 1) chemical shifts of four $\alpha$ protons at $\delta_{H} 4.25(\mathrm{dd}, J=9.6,6.6 \mathrm{~Hz}), 4.23(\mathrm{dd}$, $J=9.6,6.3 \mathrm{~Hz}), 3.84(\mathrm{dd}, J=5.0,2.1 \mathrm{~Hz})$ and $3.68(\mathrm{~d}, J=5.5 \mathrm{~Hz})$; and ${ }^{13} \mathrm{C}$ NMR spectrum (Table 1) chemical shifts of four carbonyl carbons at $\delta_{C} 171.6,171.6,169.1$ and 167.9, supported the presence of peptide fragments. The fact that compound 1 was negative to the ninhydrin test, suggested a cyclic or an N-terminus-blocked peptide. ${ }^{9}$ The identification of each amino acid unit was accomplished by detailed interpretation of the ${ }^{1} \mathrm{H}-{ }^{1} \mathrm{H}$ COSY data (Figure 2). Beginning with signals of the methine protons at $\delta_{H} 3.84$ and 3.68 , proton correlations including the upfield methyl signals readily revealed the presence of Leu and Ile residues. Also illustrated were two series of similar proton correlations containing signals of the methine protons at $\delta_{\mathrm{H}} 4.25$ and 4.23 in the ${ }^{1} \mathrm{H}$ NMR spectrum, which were interpreted to be two Pro residues. Confirmation of the spectral interpretation as well as the stereo-chemical assignment of each amino acid residue was established by Marfey's methods. ${ }^{4}$ Acid-catalyzed hydrolysis of $\mathbf{1}$ followed by treatment with L-Marfey's reagent and HPLC analysis showed that Leu and Pro had the L-configuration. The stereochemistry at the side chain of the Ile residue was also determined to be $2 S, 3 S$ on the basis of HPLC coinjection with derivatives prepared from both Ile and allo-Ile. Thus, compound 1 consisted of all L-forms of Ile, Leu, Pro (I) and Pro (II).

${ }^{1}$ Guangxi Key Laboratory of Marine Environmental Science, Guangxi Academy of Sciences, Nanning, China; ${ }^{2}$ Key Laboratory of Plant Resources Conservation and Sustainable Utilization, South China Botanical Garden, Chinese Academy of Sciences, Guangzhou, China and ${ }^{3}$ Department of Pharmacy and Pharmacology, University of Bath, Bath, UK Correspondence: Dr R-M Huang, Key Laboratory of Plant Resources Conservation and Sustainable Utilization, South China Botanical Garden, Chinese Academy of Sciences, 723 Xingke Road, Tianhe District, Guangzhou 510650, China.

E-mail: huang_riming@hotmail.com

Received 10 January 2014; revised 18 February 2014; accepted 27 February 2014; published online 2 April 2014 
Further structural assignment and sequencing of the amino acid residues were accomplished with the aid of $\mathrm{HMBC}$ experiments (Figure 2). HMBC correlations of $\mathrm{C}-\mathrm{1}^{\prime}$ with $\mathrm{H}-2, \mathrm{H}-5$ and $\mathrm{H}-3^{\prime}$ placed a peptide linkage between Leu and Pro (I). Correlations of C- $1^{\prime \prime}$ with $\mathrm{H}-2^{\prime}$ and $\mathrm{H}-3^{\prime \prime}$ also denoted a peptide linkage between Leu and Pro (II). The placement of a peptide linkage between Ile and Pro (I) was secured by HMBC correlations of $\mathrm{C}-1$ with protons $\mathrm{H}-2^{\prime \prime \prime}$ and $\mathrm{H}-3$. The placement of a peptide linkage between Ile and Pro (II) was confirmed by HMBC correlations of $\mathrm{C}-1^{\prime \prime \prime}$ with $\mathrm{H}-2^{\prime \prime}, \mathrm{H}-5^{\prime \prime}$ and $\mathrm{H}-3^{\prime \prime \prime}$. A literature survey revealed that fenestin $\mathrm{A},{ }^{10}$ a cyclic tetrapeptide from the marine sponge Leucophloeus fenestrata, had the same amino acid composition but differed from 1 in the sequence of amino acid residues. In the MS, fragment ion at $\mathrm{m} / \mathrm{z} 210$ is

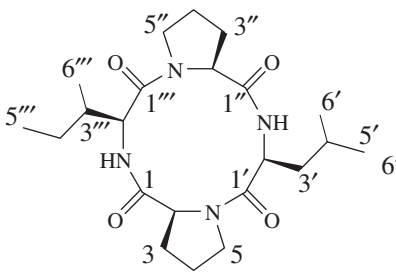

1

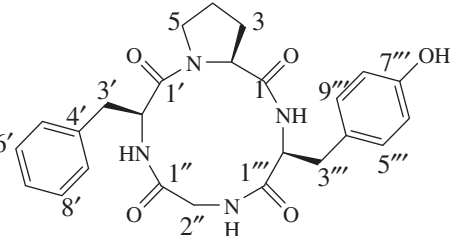

2
Figure 1 The structures of compounds 1 and 2 .

Table $1{ }^{1} \mathrm{H}$ and ${ }^{13} \mathrm{C}$ NMR data for 1 (600 and $150 \mathrm{MHz}, \mathrm{CD}_{3} \mathrm{OD}$, $\delta$ in p.p.m.)

\begin{tabular}{|c|c|c|c|}
\hline Residue & Position & $\delta_{\mathrm{H}}$ (mult., $J$ in $\mathrm{Hz}$ ) & $\delta_{C}(m u l t)$ \\
\hline \multirow[t]{8}{*}{ Pro (I) } & 1 & & 171.6, C \\
\hline & 2 & $4.25, \mathrm{dd}(9.6,6.6)$ & $59.3, \mathrm{CH}$ \\
\hline & 3 & $2.35, \mathrm{~m}$ & $30.3, \mathrm{CH}_{2}$ \\
\hline & 3 & $1.93, \mathrm{~m}$ & \\
\hline & $4 \alpha$ & $2.00, \mathrm{~m}$ & $23.1, \mathrm{CH}_{2}$ \\
\hline & $4 \beta$ & $1.95, \mathrm{~m}$ & \\
\hline & $5 \alpha$ & $3.55, \mathrm{~m}$ & $46.8, \mathrm{CH}_{2}$ \\
\hline & $5 \beta$ & $3.48, \mathrm{~m}$ & \\
\hline \multirow[t]{7}{*}{ Leu } & $1^{\prime}$ & & 169.1, C \\
\hline & $2^{\prime}$ & $3.84, \mathrm{dd}(5.0,2.1)$ & $57.1, \mathrm{CH}$ \\
\hline & $3^{\prime} \alpha$ & $1.68, \mathrm{~m}$ & 43.6, $\mathrm{CH}_{2}$ \\
\hline & $3^{\prime} \beta$ & $1.57, \mathrm{~m}$ & \\
\hline & $4^{\prime}$ & $1.77, \mathrm{~m}$ & $25.5, \mathrm{CH}$ \\
\hline & $5^{\prime}$ & $0.99, \mathrm{~d}(5.5)$ & 23.3, $\mathrm{CH}_{3}$ \\
\hline & $6^{\prime}$ & $0.99, \mathrm{~d}(5.5)$ & $21.9, \mathrm{CH}_{3}$ \\
\hline \multirow[t]{8}{*}{ Pro (II) } & $1^{\prime \prime}$ & & 171.6, C \\
\hline & $2^{\prime \prime}$ & 4.23, dd $(9.6,6.3)$ & $59.7, \mathrm{CH}$ \\
\hline & $3^{\prime \prime} \alpha$ & $2.33, \mathrm{~m}$ & $29.9, \mathrm{CH}_{2}$ \\
\hline & $3^{\prime \prime} \beta$ & $1.91, \mathrm{~m}$ & \\
\hline & $4^{\prime \prime} \alpha$ & $2.02, \mathrm{~m}$ & 23.3, $\mathrm{CH}_{2}$ \\
\hline & $4^{\prime \prime} \beta$ & $1.93, \mathrm{~m}$ & \\
\hline & $5^{\prime \prime} \alpha$ & $3.51, \mathrm{~m}$ & 46.7, $\mathrm{CH}_{2}$ \\
\hline & $5^{\prime \prime} \beta$ & $3.49, \mathrm{~m}$ & \\
\hline \multirow[t]{6}{*}{ Ile } & $1^{\prime \prime \prime}$ & & 167.9, C \\
\hline & $2^{\prime \prime \prime}$ & $3.68, d(5.5)$ & $63.4, \mathrm{CH}$ \\
\hline & $3^{\prime \prime \prime}$ & $1.90, \mathrm{~m}$ & $41.0, \mathrm{CH}$ \\
\hline & $4^{\prime \prime \prime}$ & $1.59, \mathrm{~m}$ & 26.0, $\mathrm{CH}_{2}$ \\
\hline & $5^{\prime \prime \prime}$ & $0.96, \mathrm{t}(7.0)$ & $11.6, \mathrm{CH}_{3}$ \\
\hline & $6^{\prime \prime \prime}$ & $1.00, \mathrm{~d}(7.3)$ & 16.7, $\mathrm{CH}_{3}$ \\
\hline
\end{tabular}

consistent with Pro-Leu or Pro-Ile fragments. These data are consistent with cyclo-(Leu-Pro-Ile-Pro) or with cyclo-(Leu-Ile-ProPro), however, by analogy with fenestin A, the latter structure would be expected to show a fragment at $m / z 194$ for Pro-Pro in the MS. The combination of these data confirmed the structure of 1 as cyclo(Leu-Pro-Ile-Pro).

Compound 2 was obtained as a white amorphous solid and had a molecular ion peak at $m / z$ 465.2138 $[\mathrm{M}+\mathrm{H}]^{+}$(calcd for $\left.\mathrm{C}_{25} \mathrm{H}_{29} \mathrm{~N}_{4} \mathrm{O}_{5}, 465.2136\right)$ by HR-ESI-MS consistent with the molecular formula $\mathrm{C}_{25} \mathrm{H}_{28} \mathrm{~N}_{4} \mathrm{O}_{5}$. In ${ }^{13} \mathrm{C}$ NMR spectrum (Table 2), in addition to signals corresponding to the side chains of the above amino acids, four carbonyl signals at $\delta_{\mathrm{C}} 168.3,167.2,165.7$ and 164.9 could be assigned as the amide carbons of Pro, Gly, Tyr and Phe, respectively,

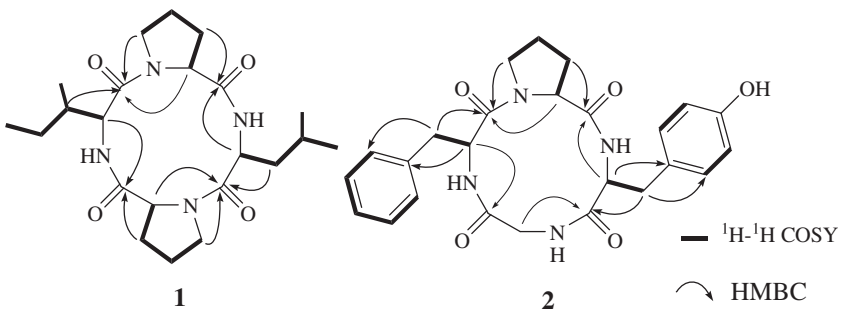

Figure 2 Key ${ }^{1} \mathrm{H}-{ }^{1} \mathrm{HCOSY}$ correlations and $\mathrm{HMBC}$ correlations of $\mathbf{1}$ and $\mathbf{2}$.

Table $2{ }^{1} \mathrm{H}$ and ${ }^{13} \mathrm{C}$ NMR data for 2 (600 and $150 \mathrm{MHz}$, DMSO- $d_{6}$, $\delta$ in p.p.m.)

\begin{tabular}{|c|c|c|c|}
\hline Residue & Position & $\delta_{\mathrm{H}}($ mult., $J$ in $\mathrm{Hz})$ & $\delta_{C}(m u l t)$ \\
\hline \multirow[t]{8}{*}{ Pro } & 1 & & 168.3, C \\
\hline & 2 & 4.06, dd $(9.6,6.3)$ & $55.5, \mathrm{CH}$ \\
\hline & $3 \alpha$ & $1.98, \mathrm{~m}$ & 28.6, $\mathrm{CH}_{2}$ \\
\hline & $3 \beta$ & $1.51, \mathrm{~m}$ & \\
\hline & $4 \alpha$ & $1.78, \mathrm{~m}$ & 21.3, $\mathrm{CH}_{2}$ \\
\hline & $4 \beta$ & $1.51, \mathrm{~m}$ & \\
\hline & $5 \alpha$ & $3.36, \mathrm{~m}$ & $44.6, \mathrm{CH}_{2}$ \\
\hline & $5 \beta$ & $3.11, \mathrm{~m}$ & \\
\hline \multirow[t]{9}{*}{ Phe } & $1^{\prime}$ & & $164.9, \mathrm{C}$ \\
\hline & $2^{\prime}$ & $3.91, \mathrm{dd}(5.5,4.8)$ & $58.1, \mathrm{CH}$ \\
\hline & $3^{\prime} \alpha$ & 3.01, dd $(13.6,4.8)$ & $38.8, \mathrm{CH}_{2}$ \\
\hline & $3^{\prime} \beta$ & 2.87, dd $(13.6,5.5)$ & \\
\hline & $4^{\prime}$ & & $136.0, \mathrm{C}$ \\
\hline & $5^{\prime} / 9^{\prime}$ & $7.20, \mathrm{~d}(7.2)$ & $130.8,2 \mathrm{CH}$ \\
\hline & $6^{\prime} / 8^{\prime}$ & $7.28, \mathrm{dd}(7.2,5.5)$ & $128.1,2 \mathrm{CH}$ \\
\hline & $7^{\prime}$ & $7.28, \mathrm{t}(5.5)$ & $126.8, \mathrm{CH}$ \\
\hline & $\mathrm{NH}$ & $8.11, \mathrm{~s}$ & \\
\hline \multirow[t]{4}{*}{ Gly } & $1^{\prime \prime}$ & & 167.2, C \\
\hline & $2^{\prime \prime} \alpha$ & $3.34, d(11.0)$ & 43.7, $\mathrm{CH}_{2}$ \\
\hline & $2^{\prime \prime} \beta$ & $3.11, \mathrm{~d}(11.0)$ & \\
\hline & $\mathrm{NH}$ & $8.11, \mathrm{~s}$ & \\
\hline \multirow[t]{9}{*}{ Tyr } & $1^{\prime \prime \prime}$ & & 165.7, C \\
\hline & $2^{\prime \prime \prime}$ & 2.85, dd $(6.2,3.4)$ & $57.2, \mathrm{CH}$ \\
\hline & $3^{\prime \prime \prime} \alpha$ & 3.00, dd $(12.6,6.2)$ & $38.6, \mathrm{CH}_{2}$ \\
\hline & $3^{\prime \prime \prime} \beta$ & 2.77, dd $(12.6,3.4)$ & \\
\hline & $4^{\prime \prime \prime}$ & & $125.9, \mathrm{C}$ \\
\hline & $5^{\prime \prime \prime} / 9^{\prime \prime \prime}$ & $6.66, d(7.0)$ & $115.1,2 \mathrm{CH}$ \\
\hline & $6^{\prime \prime \prime} / 8^{\prime \prime \prime}$ & $6.90, d(7.0)$ & $135.9,2 \mathrm{CH}$ \\
\hline & $7^{\prime \prime \prime}$ & & 156.3, C \\
\hline & $\mathrm{NH}$ & $7.88, \mathrm{~s}$ & \\
\hline
\end{tabular}


by the ${ }^{3} J_{\mathrm{CH}}$ correlation from their $\beta$ protons (Figure 2). The ${ }^{1} \mathrm{H}$ NMR (Table 2) of 2 showed two $\alpha$ protons at $\delta_{\mathrm{H}} 4.06$ (dd, $J=9.6,6.3 \mathrm{~Hz}$ ) and $3.91(\mathrm{dd}, J=5.5,4.8 \mathrm{~Hz}$ ) while a third $\alpha$ proton was observed upfield at $\delta_{\mathrm{H}} 2.85(\mathrm{dd}, J=6.2,3.4 \mathrm{~Hz})$. The side chain signals for the individual acids were determined by ${ }^{1} \mathrm{H}-{ }^{1} \mathrm{H}$ COSY data (Figure 2) and were fully consistent with the presence of Pro, Phe, Gly and Tyr residues. Confirmation of the spectral interpretation as well as the stereo-chemical assignment of each amino acid residue was established by Marfey methods. ${ }^{4}$ Acid-catalyzed hydrolysis of $\mathbf{2}$ followed by treatment with L-Marfey's reagent and HPLC analysis showed that Phe and Pro had the L-configuration. The stereochemistry at the side chain of the Ile residue was also determined to be $2 S$ on the basis of HPLC coinjection with derivatives prepared from both Tyr and Phe. Thus, compound 2 consisted of all L-forms of Pro, Tyr and Phe.

Further structural assignment and sequencing of the amino acid residues was accomplished with the aid of $\mathrm{HMBC}$ experiments (Figure 2). HMBC correlations of $\mathrm{C}-1^{\prime}$ with $\mathrm{H}-2, \mathrm{H}-5$ and $\mathrm{H}-3^{\prime}$ placed a peptide linkage between Phe and Pro. Correlations of C- $1^{\prime \prime}$ with $\mathrm{H}-2^{\prime}$, denoted a peptide linkage between Phe and Gly. The placement of a peptide linkage between Gly and Tyr was secured by HMBC correlations of $\mathrm{C}^{-1}{ }^{\prime \prime \prime}$ with protons $\mathrm{H}_{\alpha}-2^{\prime \prime}$ and $\mathrm{H}_{\beta}-2^{\prime \prime}$. The placement of a peptide linkage between Tyr and Pro was confirmed by $\mathrm{HMBC}$ correlations of $\mathrm{C}-1$ with $\mathrm{H}-2^{\prime \prime \prime}$ and $\mathrm{H}-3$. In the MS, fragment ions at $\mathrm{m} / \mathrm{z}$ 260, 244, 220 and 204 were consistent with Pro-Tyr, ProPhe, Tyr-Gly and Phe-Gly fragments, respectively, which were consistent with cyclo-(Phe-Pro-Tyr-Gly). Thus, the structure of $\mathbf{2}$ was determined to be cyclo-(Phe-Pro-Tyr-Gly).

The cytotoxicities of compounds $\mathbf{1}$ and $\mathbf{2}$ were assayed in vitro against the HepG2 and HeLa cell lines by MTT method. ${ }^{11}$ Compound 1 exhibited cytotoxic activity with $\mathrm{IC}_{50}$ values of $26.6 \mu \mathrm{M}$ and $34.7 \mu \mathrm{M}$, respectively. The values of compound 2 were $38.2 \mu \mathrm{m}$ and $46.1 \mu \mathrm{M}$, respectively.

\section{ACKNOWLEDGEMENTS}

This study was supported by grants from National Natural Science Foundation of China (No. 31100260, 81260480), Knowledge Innovation Program of Chinese Academy of Sciences (KSCX2-EW-J-28), Natural Science Foundation of Guangxi (2011GXNSFE018002, 2011GXNSFB018035, 2011GXNSFA018108, 2012GXNSFAA053160, 2012GXNSFBA053068). R-MH acknowledges a CAS Academic Visitor Fellowship and thanks Dr Ian S Blagbrough, University of Bath, for helpful discussions.

1 Blunt, J. W., Copp, B. R., Keyzers, R. A., Munro, M. H. G. \& Prinsep, M. R. Marine natural products. Nat. Prod. Rep. 30, 237-323 (2013).

2 Debbab, A., Aly, A. H., Lin, W. H. \& Proksch, P. Bioactive compounds from marine bacteria and fungi. Microb. Biotechnol. 3, 544-563 (2010).

3 Olano, C., Mendez, C. \& Salas, J. A. Antitumor compounds from marine actinomycetes. Mar. Drugs. 7, 210-248 (2009).

4 Shin, J., Seo, Y., Lee, H. S., Rho, J. R. \& Mo, S. J. A new cyclic peptide from a marinederived bacterium of the genus Nocardiopsis. J. Nat. Prod. 66, 883-884 (2003).

5 Fenical, W. Chemical studies of marine bacteria: developing a new fesource. Chem. Rev. 93, 1673-1683 (1993).

$6 \mathrm{He}, \mathrm{F}$. et al. Asperterrestide A, a cytotoxic cyclic tetrapeptide from the marine-derived fungus Aspergillus terreus SCSGAF0162. J. Nat. Prod. 76, 1182-1186 (2013).

7 Romano, A., Vitullo, D., Di, P. A., Lima, G. \& Lanzotti, V. Antifungal lipopeptides from Bacillus amyloliquefaciens Strain B07. J. Nat. Prod. 74, 145-151 (2011).

8 Hiradate, S., Yoshida, S., Sugie, H., Yada, H. \& Fujii, Y. Mulberry anthracnose antagonists (iturins) produced by Bacillus amyloliquefaciens RC-2. Phytochemistry 61, 693-698 (2002).

9 Huang, R. M. et al. A new 1,4-diazepine from South China Sea marine sponge Callyspongia species. Molecules. 15, 871-877 (2010).

10 Omar, S., Tenenbaum, L., Manes, L. V. \& Crews, P. Novel marine dponge derived amino-acids.7. The fenestins. Tetrahedron Lett. 29, 5489-5492 (1988).

11 Mosmann, T. Rapid colorimetric assay for cellular growth and survival: application to proliferation and cytotoxicity assays. J. Immunol. Methods 65, 55-63 (1983). 